\title{
EZR Gene
}

National Cancer Institute

\section{Source}

National Cancer Institute. EZR Gene. NCI Thesaurus. Code C68722.

This gene plays a role in cellular structure. 